\title{
1. What Jensen and Meckling really said about the public company
}

\author{
Brian R. Cheffins ${ }^{1}$
}

\section{INTRODUCTION}

Michael Jensen and William Meckling have been christened "academic gods"2 on the strength of their 1976 Journal of Financial Economics article "Theory of the Firm: Managerial Behavior, Agency Costs and Ownership Structure."” This follows on from "Theory of the Firm" being probably the most widely cited academic article that engages with corporate personhood and corporate purpose. Accepted views of classic works in an academic discipline often exaggerate or distort the original text. ${ }^{4}$ As this chapter will discuss, Jensen and Meckling's 1976 article is an exemplary example.

The public company is terrain where the disconnect between what Jensen and Meckling supposedly said and actually said is particularly pronounced. This, moreover, has not been a case of "no harm, no foul." Instead, the mistranslation of what Jensen and Meckling said has meant "Theory of the Firm" has been blamed incorrectly for fostering key governance changes many believe have gone awry. For instance, various critics of a late 20th-century prioritization of shareholder value maintain Jensen and Meckling provided pivotal intellectual cover for this trend. Instead, Jensen and Meckling, having characterized the firm as a nexus of contracting relations in their famous 1976 article, suggested that it was misconceived to seek to attribute a corporate purpose to such a nexus.

Jensen and Meckling similarly stand accused of recommending for the public company governance cures many believe ended up being worse than the disease. For instance, they reputedly were influential intellectual cheerleaders for hostile takeovers in advance of a 1980s takeover boom that "transformed the economic landscape ... with what to many seemed like great brutality and waste." Also, Jensen and Meckling ostensibly helped to swing public companies around to the idea of incentivizing executive compensation, a trend that would in the

1 I would like to thank the editors of this volume and the participants in the Virtual Book Colloquium the editors organized for helpful feedback. The usual caveat applies.

2 William W. Bratton, Collected Lectures and Talks on Corporate Law, Legal Theory, History, Finance, and Governance, 42 SeAtTLE U. L. REV. 755, 816 (2019).

3 Michael C. Jensen \& William H. Meckling, Theory of the Firm: Managerial Behavior, Agency Costs and Ownership Structure, 3 J. Fin. ECON. 305 (1976).

4 Mark S. Mizruchi \& Lisa C. Fein, The Social Construction of Organizational Knowledge: A Study of the Uses of Coercive, Mimetic, and Normative Isomorphism, 44 ADMIN. SCI. Q. 653 (1999); Mark S. Mizruchi \& Daniel Hirschman, The Modern Corporation as Social Construction, 33 SeAttle U. L. REV. 1065,1065 (2010).

5 It cannot be taken for granted that selective treatment of classic works will be a source of concern-Mizruchi \& Fein, supra note 4, 680.

6 Justin Fox, The Myth of the Rational Market: A History of Risk, Reward, and Delusion on Wall Street 168 (2011). 
1990s become so lucrative for senior management that Jensen himself said in 2002 "I'm now a critic of where we got to." " In fact, Jensen and Meckling were public company optimists in "Theory of the Firm" who had little to say about changing the corporate landscape, including with respect to takeovers and the overhauling of managerial compensation.

This chapter canvasses the wide gap between what Jensen and Meckling supposedly said about the public company and what they actually said, and explains how this discrepancy occurred. Part II of the chapter draws attention to the fame that Jensen and Meckling's "Theory of the Firm" has enjoyed in academic circles, emphasizing in so doing the article's reputation as a catalyst for change in the public company realm. Part III describes the public-company-related exaggerations and distortions that have arisen in relation to the article. Part IV accounts for the substantial disconnect between what Jensen and Meckling supposedly and actually said, focusing particularly on a dramatic shift by Jensen from public company optimist to public company pessimist in the late 1980s and early 1990s. Part V concludes.

\section{JENSEN AND MECKLING'S LONG SHADOW}

Evidence abounds of the academic notoriety of Jensen and Meckling's "Theory of the Firm." It is currently one of the most-referenced papers in various fields, including economics, finance, accounting and corporate governance, and may well be the most cited article ever about business. ${ }^{8}$ According to Google Scholar, "Theory of the Firm" has been cited more than 100,000 times - approximately four times as often as Adolf Berle and Gardiner Means' classic 1932 study of corporate America, The Modern Corporation \& Private Property. ${ }^{9}$ Moreover, Jensen and Meckling's article is hardly destined for intellectual obscurity. Again according to Google, "Theory of the Firm" was cited nearly 10,000 times in 2020 alone.

"Theory of the Firm" is best known for its contribution to agency theory, which has had a profound intellectual impact in the realms of economics, corporate governance, corporate law and organizational behavior. ${ }^{10}$ Jensen and Meckling defined "an agency relationship as a contract under which one or more persons (the principal(s)) engage another person (the agent) to perform some service on their behalf which involves delegating some decision making authority to the agent." "11 Jensen and Meckling acknowledged agents would not always make choices that maximized the welfare of their principals. Principals and agents would take steps, however, to reduce this "residual loss," meaning agency costs were "the sum of: (1) the

\footnotetext{
7 John Cassidy, The Greed Cycle, New Yorker, Sept. 23, 2002, 64, 75.

8 David Gindis, On the Origins, Meaning and Influence of Jensen and Meckling's Definition of the Firm, 72 Oxf. Econ. PAPers 966, 966 (2020); A New Idolatry, Economist, April 24, 2010, 65.

9 Adolf A. Berle \& Gardiner C. Means, The Modern Corporation \& Private Property (1932). This pattern has prevailed since the 1980s-Jason Scott Johnston, The Influence of the Nature of the Firm on the Theory of Corporate Law, 18 J. CORP. L. 213, 230-31 (1993).

10 Rakesh Khurana, From Higher Aims to Hired Hands: The Social Transformation of American Business Schools and the Unfulfilled Promise of Management as a Profession 318 (2007); Ronald J. Gilson, From Corporate Law to Corporate Governance in The OxFord HandBoOK OF Corporate LaW and Governance 3, 4 (Jeffrey N. Gordon \& Wolf-Georg Ringe eds., 2018).

11 Jensen and Meckling, supra note 3, 308.
} 


\section{Research handbook on corporate purpose and personhood}

monitoring expenditures by the principal, (2) the bonding expenditures by the agent, (3) the residual loss." 12

While "Theory of the Firm" would become "[t]he agency cost urtext," 13 Jensen and Meckling were not the originators of agency theory. ${ }^{14}$ For instance, in a 1973 article offering a theoretical analysis of agent pay-off structures, economist Stephen Ross noted that "[e]xamples of agency are universal." ${ }^{15}$ Nevertheless, Jensen and Meckling, by putting agency costs at the center of their 56-page analysis of the ownership structure of firms, ${ }^{16}$ provided a wide-ranging research agenda that would jump start agency theory. ${ }^{17}$ Jensen and Meckling's framework would in time serve as a departure point for analysis in dozens if not hundreds of papers by economists, legal academics and business scholars. ${ }^{18}$ Jensen, who wrote additional influential articles about agency costs in the $1980 \mathrm{~s},{ }^{19}$ would become "the éminence grise of agency theory." ${ }^{20}$

Jensen and Meckling's 1976 article also achieved fame due to their characterization of the firm as "a nexus for contracting relationships." ${ }^{21}$ While incorporated entities are vested formally with legal personality, ${ }^{22}$ Jensen and Meckling treated the corporate form as "a mere legal fiction" 23 of minimal analytical significance. They said crucial questions, such as "why particular sets of contractual relations arise for various types of organizations, what the consequences of these contractual relations are, and how they are affected by changes exogenous to the organization" should be addressed with "the essential contractual nature of firms" as the departure point. ${ }^{24}$

Some credit Jensen and Meckling with describing the corporation as a "nexus of contracts. ${ }^{25}$ In fact, fellow economist Eugene Fama coined the term in $1980 .{ }^{26}$ Nevertheless,

Id.

13 Bratton, supra note 2, 809.

14 Barry M. Mitnick, Origin of the Theory of Agency: An Account by One of the Theory's Originators, unpublished working paper, 7 (2019).

15 Stephen A. Ross, The Economic Theory of Agency: The Principal's Problem, 63 Amer. Econ. REV. 134, 134 (1973).

16 Jensen and Meckling, supra note 3, 305-6, 308.

17 Martin Gelter, The Pension System and the Rise of Shareholder Primacy, 43 Seton Hall L. Rev. 909, 913 (2013); J.B. Heaton, Corporate Governance and the Cult of Agency, 64 VILL. L. REv. 201, 210 (2019).

18 Gelter, supra note 17, 913; Margaret M. Blair, Institutionalists, Neoclassicals and Team Production, 43 BRIT. J. Indust. Rel. 605, 606 (2005).

19 Eugene F. Fama \& Michael C. Jensen, Separation of Ownership and Control, 26 J. L. \& Econ. 301 (1983); Eugene F. Fama \& Michael C. Jensen, Agency Problems and Residual Claims, 26 J. L. \& Econ. 327 (1983); Michael C. Jensen, Agency Costs of Free Cash Flow, Corporate Finance, and Takeovers, 76 AmER. ECON. Rev. 323 (1986).

20 Simon London, Why Cash has Become King Once Again, Fin. Times, Feb. 14, 2005, 12. See also Thomas Clarke, The Long Road to Reformulating the Understanding of Directors' Duties: Legalizing Team Production Theory, 38 SeattLe U. L. Rev. 433, 452 (2015) ("arch-priest of agency theory").

21 Jensen and Meckling, supra note 3, 310-11.

22 Robert C. Clark, Corporate Law 15, 17 (1986).

23 Jensen and Meckling, supra note 3, 311.

$24 \quad I d$.

25 See, for example, Jeffrey N. Gordon, The Mandatory Structure of Corporate Law, 89 Colum. L. Rev. 1549, 1549, n. 1 (1989); Melvin A. Eisenberg, The Conception that the Corporation Is a Nexus of Contracts, and the Dual Nature of the Firm, 24 J. CoRP. L. 819, 819 (1999).

26 Eugene F. Fama, Agency Problems and the Theory of the Firm, 88 J. PoL. Econ. 288, 290 (1980);

Marc T. Moore, Corporate Governance in The Shadow of the State 72, n. 50 (2013). 
Jensen and Meckling's "Theory of the Firm" would have a profound impact on the manner in which the corporation was conceptualized. The article provided the primary intellectual foundation for the development of an economically-oriented "contractarian" model of the corporation that fostered intense debate in corporate law circles in the 1980s before moving to the theoretical forefront in the $1990 \mathrm{~s}$, at least in the United States..$^{27}$ The nexus-of-contracts conception of the corporation has continued to loom large in corporate law scholarship in the years since. ${ }^{28}$ Jensen and Meckling's 1976 article correspondingly is "one of the most canonic and influential articles in the field of theory of the firm." 29

Jensen and Meckling's agency cost and contracting nexus insights could be relevant for a firm regardless of its size or ownership structure. Jensen and Meckling indeed commenced their theoretical analysis of firms assuming that they were dealing with a firm of a fixed size with an owner-manager who owned all of the equity and derived insights by relaxing these assumptions. ${ }^{30}$ Nevertheless, Jensen and Meckling's analysis resonated particularly for the publicly traded firm with widely dispersed share ownership. ${ }^{31}$ They observed "it should be no surprise to discover that the issues associated with the 'separation of ownership and control' in the modern diffuse ownership corporation are intimately associated with the general problem of agency." 32 Jensen and Meckling specifically acknowledged that Berle and Means had "popularized" in the early 1930s the potential for manager/shareholder misalignment when large American firms were publicly traded and characterized by a separation of ownership and control. ${ }^{33}$ Jensen subsequently said of the treatment of agency costs he and Meckling had provided that "[w]hile the issues are general, we developed the theory in the context of the conflicts of interest between corporate managers and outside equity and debt holders." ${ }^{34}$

Given that the public company featured prominently in Jensen and Meckling's "Theory of the Firm" and given the long intellectual shadow their article has cast, it is not surprising that the article has been drawn upon extensively in subsequent analyses of the publicly traded firm. Indeed, Jensen and Meckling's "theory of agency costs in the public corporation" has been characterized as "the dominant framework of analysis for corporate law and corporate

27 Eisenberg, supra note 25, 819 (highlighting Jensen and Meckling's role as originators of the nexus of contracts model and identifying critics); William W. Bratton, Economic Structure of the Post-Contractual Corporation, 87 Nw. U. L. Rev. 180, 184, n. 25 (1992) (identifying critics); Brian R. Cheffins, The Trajectory of (Corporate Law) Scholarship, 63 CAMBridge L. J. 456,484 (2004) (describing the 1990s dominance of the nexus of contracts model).

28 Grant M. Hayden \& Matthew T. Bodie, The Uncorporation and the Unraveling of "Nexus of Contracts” Theory, 109 Mich. L. Rev. 1127, 1130 (2011); Charles R.T. O'Kelley, Coase, Knight, and the Nexus-of-Contracts Theory of the Firm: A Reflection on Reification, Reality, and the Corporation as Entrepreneur Surrogate, 35 SeAttle UnIV. L. Rev. 1246, 1246 (2012).

29 Ron Harris, The History of Team Production Theory, 38 SeAttle Univ. L. Rev. 537, 556 (2015).

30 Jensen and Meckling, supra note 3, 313-23.

31 Heaton, supra note 17, 211; Oliver E. Williamson, Corporate Finance and Corporate Governance, 43 J. Fin. 567, 568, 583 (1988) (Jensen and Meckling's "real interest is in the diffusely owned modern corporation"); Michael S. Lubatkin, A Theory of the Firm Only a Microeconomist Could Love, 14 J. MGMt. InQUiRy 213, 214 (2005) (saying Jensen and Meckling's modeling "was intended to apply only to settings for large for-profit organizations operating in developed capital markets with widely diversified shareholdings").

32 Jensen and Meckling, supra note 3, 309.

33 Id., 327.

34 Michael C. Jensen, Agency Costs of Overvalued Equity, Fin. Mgmt., Spring 2005, 5, 6. 
governance." ${ }^{35}$ As we will see next, though, what Jensen and Meckling supposedly said about the public company has come to diverge substantially from what they actually said.

\section{JENSEN AND MECKLING'S CHARACTERIZATION OF THE PUBLIC COMPANY - SEPARATING FACT FROM FICTION}

Among those who reference Jensen and Meckling's "Theory of the Firm" a common presumption is that they were public company pessimists. With agency costs to draw upon, they reputedly characterized public companies as business enterprises hamstrung by a substantial divergence of interests between managers and shareholders that required corrective action and perhaps even full removal from public markets. In fact, Jensen and Meckling were public company admirers who were impressed by the success public companies had historically enjoyed and who engaged only in tentative speculation regarding strategies available to mitigate agency costs. This section elaborates on the differences between what Jensen and Meckling supposedly and actually said, with the focus being on the prevalence of agency costs in public companies and corporate purpose.

\section{A. The "Out of Sync" Public Company}

When "Theory of the Firm" was published in 1976 economists were not troubling themselves much with the nature of the firm. Firms were thought of as "black boxes" undeserving of close attention because of confidence that competitive forces would dispatch to oblivion any business enterprise that failed to prioritize profit-seeking. ${ }^{36}$ Jensen and Meckling specifically acknowledged that the economics profession thought about firms in this way. ${ }^{37}$ They also characterized the publicly traded firm in a manner that clashed directly with economics orthodoxy. Jensen and Meckling said that with agency costs being "an unavoidable result of the agency relationship" whenever a company had hired managers rather than having owner-managers it would not be "run in a manner so as to maximize its value." ${ }^{38}$ These were "the costs of the separation of ownership and control." 39

It has been widely assumed that when Jensen and Meckling drew attention to the downsides with the separation of ownership and control they were offering a damning indictment of public companies that implied governance adjustments were imperative. Management professor Gerald Davis says Jensen and Meckling combined their "ideas into a comprehensive critique of the Berle and Means view of the corporation" that implied it "didn't make sense" for investors to "put their savings into shares of companies."

\footnotetext{
35 Michael Klausner, Fact and Fiction in Corporate Law and Governance, 65 STAN. L. REV. 1325, 1326 (2013).

36 William W. Bratton, The "Nexus of Contracts" Corporation: A Critical Appraisal, 74 CoRNELL L. Rev. 407, 415 (1989); Marion Fourcade and Rakesh Khurana, The Social Trajectory of a Finance Professor and the Common Sense of Capital, 49 History Pol. ECON. 347, 351-52 (2017).

37 Jensen and Meckling, supra note 3, 306-7.

$38 \quad I d ., 327$.

$39 \quad I d ., 328$.

40 Gerald F. Davis, The Twilight of the Berle and Means Corporation, 34 Seattle U. L. Rev. 1121, 1127 (2011).
} 
Frank Dobbin and Jiwook Jung, Jensen and Meckling maintained the interests of executives and shareholders were "out of sync," resulting in executives "building large diversified firms to minimize the risk of failure and to raise their own salaries." ${ }^{\prime 1}$ Law professor Lynn Stout observed similarly,

Jensen and Meckling saw the passivity of dispersed shareholders in public corporations as a serious weakness that invited professional managers to neglect shareholders' interests in the pursuit of their own, leading managers to shirk or even steal from the firm. The result was the dread "agency costs" whose lurking presence in public corporations has haunted many finance economists and corporate governance experts ever since. ${ }^{42}$

Given the mid-1970s economic context it is plausible Jensen and Meckling were public company critics. In contrast with economic prosperity in the 1950s and 1960s which cast corporate America in a favorable light, throughout much of the 1970s stock prices swooned amidst growing foreign competition and a dispiriting combination of inflation and unemployment ("stagflation"). ${ }^{43}$ According to Stout, the gloomy economic context meant it was acceptable to question "the efficacy of managerial capitalism" and financial economists like Jensen and Meckling were "ready to criticize." ${ }^{44}$ Dobbin and Jung have similarly observed "[t]he stagflation of the 1970s stimulated business to search for a diagnosis and remedy. Agency theorists offered both." ${ }^{45}$ The Economist did likewise in 2002, saying that when Jensen and Meckling "first explored how companies might remedy [agency] problems" this occurred "against a backdrop of depressed share prices and lacklustre corporate performance." ${ }^{46}$

As for how the agency cost problem afflicting public companies might be addressed, the received wisdom is that Jensen and Meckling prescribed corporate governance changes as a cure. For instance, Jensen and Meckling reputedly maintained that "conflicts of interests and incentives between the management and shareholders of large public companies" were "the primary responsibility, and most formidable challenge, facing the boards and internal governance systems of public companies." "Th "Theory of the Firm" in turn supposedly "called for more independent and engaged boards to oversee and discipline top managers." 48 In addition, Jensen and Meckling ostensibly advocated executive pay reform, proposing "the best way to align the interests of managers to those of the shareholders was to tie a substantial amount of the manag-

41 Jiwook Jung \& Frank Dobbin, Finance and Institutional Investors in The Sociology OF FINANCE 52, 56 (Karin Knorr Cetina \& Alex Preda, eds., 2012).

42 Lynn A. Stout, On the Rise of Shareholder Primacy, Signs of Its Fall, and the Return of Managerialism (in the Closet), 36 Seattle UnIV. L. Rev. 1169, 1173 (2013).

43 Brian R. Cheffins, The Public Company Transformed 64, 104-5, 109-11 (2018).

44 Stout, supra note 42, 1173.

45 Jung \& Dobbin, supra note 41, 56.

46 How to Pay Bosses, Economist, Nov. 16, 2002, 86. See also Romney the Revolutionary, Economist, Jan. 14, 2012, 65; Nicholas Lemann, Transaction Man: The Rise of the Deal and The Decline of the American Dream 115 (2019).

47 Greg Brown et al., Private Equity: Accomplishments and Challenges, J. App. Corp. Fin., Summer 2020,8, 9 .

48 Yves Smith, Why the "Maximizing Shareholder Value" Theory Is Bogus, NAKEDCAPITALISM.COM, Oct. 21, 2013, available at https:/www.nakedcapitalism.com/2013/10/why-the-maximizing-shareholder -value-theory-of-corporate-governance-is-bogus.html. See also Moore, supra note 26, 82 (identifying Jensen and Meckling as "[t]he original exponents of the monitoring board hypothesis"); Jung \& Dobbin, supra note $41,56$. 


\section{Research handbook on corporate purpose and personhood}

ers' compensation to the share price." ${ }^{\prime 9}$ This reasoning reputedly prompted "a critical shift" in approach in public company boardrooms that evolved into "the prevailing theory of ... proper compensation in our society today," namely that executives "must receive a substantial portion of their pay in the form of stock-based-compensation." 50

Jensen and Meckling have been identified additionally as forceful proponents of a robust market for corporate control. They ostensibly reasoned the threat of displacement by a hostile takeover bid was for public company executives a potent and beneficial source of managerial discipline. ${ }^{51}$ Their article has likewise been cited as the inspiration for the "big idea" that companies taken off the stock market by way of a private-equity-led leveraged buyout (LBO) often would "do a better job of getting managers to maximise value than the public equity markets." 52 Michael Jensen himself accorded "Theory of the Firm" pioneering leveraged buyout status in a 2009 interview:

I had occasion to look back at the Jensen-Meckling agency paper and realized we had invented leveraged buyouts in that paper. We didn't call them that and we just talked about them instead of doing them (much to my regret). A number of years later they actually came about, which pleased me! $!^{53}$

\section{B. Jensen and Meckling as Shareholder Value Advocates}

In addition to setting out an agenda for fixing (or displacing) the public company, Jensen and Meckling supposedly sought to redirect managerial priorities in a shareholder-friendly direction. "[A] heightened awareness of the need to serve shareholders better" was a pivotal corporate governance trend as the 20 th century drew to a close. ${ }^{54}$ Prioritizing the creation of shareholder value ultimately became a hallmark of investor/public company relations in the United States. ${ }^{55}$ Jensen and Meckling are widely regarded as influential pioneering advocates of what would become known as "shareholder primacy." 56

49 Steven Pearlstein, When Shareholder Capitalism Came to Town, American Prospect, March/ April 2014, 40, 43-44. See also Stefan Stern, How to Encourage Managers to Act More Like Owners, Fin. Times, July 7, 2009, 12; Steve Denning, The Origin Of "The World's Dumbest Idea”: Milton Friedman, Forbes.com, June 26, 2013, available at https:/www.forbes.com/sites/stevedenning/2013/ 06/26/the-origin-of-the-worlds-dumbest-idea-milton-friedman/ ("the article proposed, that to ensure that the firms would focus solely on making money for the shareholders, firms should turn the executives into major shareholders, by affording them generous compensation in the form of stock").

50 Roger Martin, Fixing the Game: Bubbles, Crashes, and What Capitalism Can Learn From THE NFL 11, 13-14 (2011). See also Cassidy, supra note 7, 66-67.

51 Khurana, supra note 10, 301; Gerald F. Davis, Managed by the Markets: How Finance Reshaped America 56, n. 35 (2009); J.W. Mason, Disgorge the Cash: The Disconnect Between Corporate Borrowing and Investment, Roosevelt Institute 13 (2015).

52 A New Idolatry, supra note 8.

53 Pioneers in Finance: An Interview with Michael C. Jensen, Jesse Isidor Straus Professor of Business Administration, Emeritus, Harvard Business School, 2010 J. App. Fin., issue \#2, 7, 10.

54 Winthrop Knowlton \& Ira Millstein, Can the Board of Directors Help the American Corporation Earn the Immortality it Holds So Dear? in The U.S. Business Corporation: An Institution In Transition 169, 169 (John R. Meyer \& James M. Gustafson, eds., 1988).

55 Cheffins, supra note 43, 125, 187-88, 240-42.

56 The term "shareholder primacy" first became part of the corporate governance lexicon as the 1980s drew to a close. See Brian R. Cheffins, Stop Blaming Milton Friedman!, University of Cambridge Faculty of Law Research Paper No 9/2020, 40, n. 188 (2020), available at https://ssrn.com/abstract= 3552950 . 
Jensen and Meckling's 1976 article has been described as an enthusiastically pro-shareholder piece. Management theorist Roger Martin maintains that Jensen and Meckling argued when presenting agency theory that "the singular goal of a company should be to maximize the return to shareholders." ${ }^{57}$ Malcolm Salter, a Harvard Business School professor emeritus, contends that Jensen and Meckling "made an economically elegant case for shareholder value maximization as the only legitimate expression of corporate purpose." 58 Alexander Styhre, another management theorist, says that Jensen and Meckling's "real goal" was "to provide the capital owners ... with a legal argument that would grant shareholders (and nobody else) the right to the variable economic value generated by the firm." ${ }^{59}$

The shareholder advocacy in which Jensen and Meckling ostensibly engaged has in turn been hailed as a corporate priority game-changer. The Economist has suggested their 1976 article "inspired a seemingly irresistible movement to get managers to focus on value for shareholders." ${ }^{60}$ Anthropologist Karen Ho concurs, indicating that "Theory of the Firm" helped to make "shareholder value seem natural and self-evident." ${ }^{61}$ Economist Olivier Weinstein likewise maintains shareholder primacy was "partly founded on a specific theorization of the enterprise ... agency theory, first presented in the seminal article of Jensen and Meckling (1976). It would be hard to overestimate the huge practical and theoretical influence of this theory." ${ }^{2}$ And debates about corporate law were influenced in turn. According to corporate law scholar Bill Bratton "[s]hareholder empowerment advocates work within the Jensen and Meckling agency cost paradigm, claiming that management agency costs are excessive, and that shareholder empowerment will reduce them." ${ }^{63}$ Jensen and Meckling thus have been described as "the intellectual godfathers of the shareholder-centric corporation of the 1980s and 1990s." 64

57 Martin, supra note 50, 12-13. See also Roger Martin, It's Time to Replace the Public Corporation, Harv. Bus. Rev., Jan./Feb. 2021, 34, 36 ("the shareholder value revolution Jensen and Meckling helped trigger").

${ }_{58}$ Malcom S. Salter, Rehabilitating Corporate Purpose: How the Evolution of Corporate Purpose has Contributed to a Widening Breach Between Capitalism and Justice ... and What to Do about It, Harvard Business School Working Paper 19-104 18 (2019).

59 Alexander Styhre, Corporate Governance, the Firm and Investor Capitalism: Legal-Political and Economic Views 114 (2016). See also Rick Perlstein, Prophets of Instability, NAtion, March 17, 2020, available at https://www.thenation.com/article/culture/nicholas-lemann -transaction-man-review/ ("Theory of the Firm" was "Jensen's most influential statement" of the idea that managers' "very existence depended only on maximizing profits for stockholders"); P.M. Vasudev, Law, Economics, and Beyond: A Case for Reauthorizing the Business Corporation, 55 McGill L. J. 911 , 918-19 (2010) (maintaining a "'stock market model of corporate governance', is a feature of Jensen and Meckling's theory").

${ }_{60}$ A New Idolatry, supra note 8.

${ }_{61}$ Karen Ho, In the Name of Shareholder Value: Origin Myths of Corporations and their Ongoing Implications, 43 Seattle U. L. Rev. 609, 622 (2020).

${ }_{62}$ Olivier Weinstein, Understanding the Roots of Shareholder Primacy: The Meaning of Agency Theory, and the Conditions of its Contagion in The OxFord HandBook of THE Corporation 139, 139 (Thomas Clarke, Justin O’Brien \& Charles R.T. O'Kelley, eds., 2019).

63 Bratton, supra note 2, 806.

${ }^{64}$ Andrew Smith, Kevin Tennent \& Jason D. Russell, The Rejection of Industrial Democracy by Berle and Means and the Emergence of the Ideology of Managerialism, Econ. \& Indust. Democracy 2 (forthcoming). See also Bratton, supra note 2, 819 ("theoretical godfathers"). 


\section{Jensen and Meckling's Modest Public Company Agenda}

While the received wisdom is that Jensen and Meckling were pressing for a full-scale rewiring of the public company in "Theory of the Firm," their agenda in fact was considerably more modest. ${ }^{65}$ They were seeking to explain firms rather than lobby for dramatic change. Consider boards of directors. There was no call in "Theory of the Firm" for the standard corporate governance prescription to fortify public company boards with independent directors who would promote managerial accountability through attentive monitoring of senior executives. ${ }^{66}$ Instead, Jensen and Meckling simply lumped executives and directors together as managers. ${ }^{67}$ They did not use the term "executives" anywhere in their article, they referred to boards only once and they mentioned "directors" only twice, including once in a quote from Adam Smith's 1776 classic The Wealth of Nations. ${ }^{68}$

With respect to executive pay, Jensen and Meckling acknowledged that "the establishment of incentive compensation systems which serve to more closely identify the manager's interests with those of the outside equity holders" was one of a number of methods available to discourage managers from seeking to capture "non-pecuniary benefits." ${ }^{69}$ They also noted that establishing "incentive compensation systems for the manager" that "in effect give him a claim on the upper tail of the outcome distribution" was a strategy that could be deployed to address concerns that "large publicly held corporations seem to behave in a risk averse way to the detriment of the equity holders." 70 These, however, were little more than tentative conjectures. Jensen, in a 1990 Harvard Business Review article co-authored with Kevin Murphy, chastised public companies for paying executives like bureaucrats and lobbied forcefully in favor of compensation that aligned pay with performance. ${ }^{71}$ Such criticism and advocacy was absent in "Theory of the Firm".

There was similar reticence with the market for corporate control. Jensen was a leading advocate of takeovers during the 1980s, praising the pressure they brought to bear on companies afflicted with high managerial agency costs. ${ }^{72}$ Such cheerleading did not feature in "Theory of the Firm". Jensen and Meckling noted that in public companies there were occasional "conflicts for control" (they did not use the term "takeover" in their article) but said that "[f]urther analysis of these issues is left to the future." 73

The situation was similar with public-to-private buyouts of publicly traded corporations. Jensen and Meckling acknowledged that if owners of manager-operated firms (i.e. sharehold-

65 William W. Bratton \& Simone M. Sepe, Corporate Law and the Myth of Efficient Market Control, 105 CoRnell L. Rev. 675, 687 (2020) ("The J-M model, in effect, held out a blank canvas on which legal theorists could paint in a thicker description").

66 On the standard governance prescription regarding boards, see MARC Moore \& Martin Petrin, Corporate Governance: Law, Regulation and Theory 171 (2017).

67 Dalia Tsuk Mitchell, Status Bound: The Twentieth Century Evolution of Directors' Liability, 5

N.Y.U. J. L. \& Bus. 63, 129 (2009).

${ }_{68}$ Jensen and Meckling, supra note 3, 305 (quoting The Wealth of NATions), 352.

69 Id., 323.

70 Id.

71 Michael C. Jensen \& Kevin J. Murphy, CEO Incentives - It's Not How Much You Pay, But How, Harv. Bus. Rev., May/June 1990, 138.

72 Michael C. Jensen, Takeovers: Folklore and Science, Harv. Bus. Rev., Nov./Dec. 1984, 109; Michael C. Jensen, How to Detect a Prime Takeover Target, N.Y. Times, March 6, 1986, F3.

73 Jensen and Meckling, supra note 3, 352. 
ers of public companies) sold out to "a single individual with appropriate managerial talents and with sufficiently large personal wealth" agency costs could disappear. ${ }^{74}$ Law professor Nicholas Wolfson wrote in 1980 that the prospect of substantially reducing agency costs could provide "a powerful economic justification for going private." 75 Nevertheless, Jensen and Meckling themselves were treating a public-to-private transaction as a theoretical possibility, not a realistic business strategy. This is not surprising given that it was only in 1978 that leveraged buyout pioneers Kohlberg, Kravis and Roberts (KKR) launched the first private equity fund with a specific mandate to execute public-to-private buyouts. ${ }^{76}$

\section{Side-Stepping Corporate Purpose}

In addition to refraining from lobbying for governance changes for public companies Jensen and Meckling steered clear of urging executives to prioritize shareholders. Again, they argued that a corporation was a mere nexus of contracting relationships, and thus of minimal independent analytical significance. ${ }^{77}$ That meant, according to Jensen and Meckling, that it was "seriously misleading" to personalize corporations "by asking questions such as "what should be the objective function of the firm." "78 After all, a company, as a mere contractual artefact, logically could not have a motivating purpose. ${ }^{79}$

Having sidestepped the corporate purpose issue, Jensen and Meckling could hardly turn around and lobby companies to maximize shareholder value. Similarly, Jensen and Meckling's characterization of the company as a nexus of contracting relationships did not provide an obvious foundation for assertions regarding corporate priorities. With shareholders in a company being merely one constituency amongst the contractual nexus a firm represents, there is no intrinsic contractarian justification for shareholder primacy. ${ }^{80}$

While Jensen and Meckling side-stepped the corporate purpose issue, it is certainly possible to argue in favor of a pre-eminent governance position for shareholders from a contractarian perspective. Within the corporate contractual nexus shareholders can be thought of as the "residual" claimants in the sense the return on their investment varies in accordance with what remains after fixed claims a company is obliged to meet have been satisfied. ${ }^{81}$ Shareholders, due to the open-ended nature of an investment in shares, arguably need governance rights in a way that other constituencies affiliated with corporations do not. ${ }^{82}$ Also, with shareholder returns being determined by the net cash flow companies generate over time after all fixed claims have been accounted for, the governance pre-eminence of shareholders can be defended

\footnotetext{
Id., 329, 333.

Nicholas Wolfson, A Critique of Corporate Law, 34 U. Miami L. Rev. 959, 979 (1980).

Brian Cheffins \& John Armour, The Eclipse of Private Equity, 33 Del. J. Corp. L. 1, 18 (2008).

Supra note 23 and accompanying text.

Jensen and Meckling, supra note 3, 311.

William H. Meckling, Values and the Choice of the Model of the Individual in the Social Sciences, 112 Schweizerische Zeitschrift fur Volkswirtshaft und Statistik Revue Suisse D'Economie Politique et de Statistique 548, 559 (1976).

80 Brian R. Cheffins, The Team Production Model as a Paradigm, 38 Seattle U. L. Rev. 397, 408

81 Cheffins, supra note 27, 484.
} (2015).

82 Id. 
on the basis that a "rising tide of corporate profits will raise all ships." ${ }^{93}$ Though some have suggested otherwise, ${ }^{84}$ "Theory of the Firm" did not offer any such residual claimant-based justifications for shareholder primacy. Such reasoning would be advanced subsequently as the literature on agency costs developed, a process to which Jensen would contribute substantially in two 1983 articles co-written with Eugene Fama. ${ }^{85}$

\section{E. Jensen and Meckling's Admiration of the Public Company}

Why were Jensen and Meckling reticent about condemning the public company as "out of sync" and proposing changes? One reason, canvassed in the next section of this chapter, is that "Theory of the Firm" was a paper written by academics embarking on an intellectual journey rather than being the product of fully developed theorizing regarding firms. Another explanation, canvassed here, is that Jensen and Meckling evinced considerable admiration for the public company. They concluded "Theory of the Firm" by saying " $[\mathrm{t}]$ he publicly held business corporation is an awesome social invention." ${ }^{\prime 66}$ Given Jensen and Meckling's favorable assessment of the public company, neither harsh criticism nor robust prescriptions for improvement were likely to follow.

For Jensen and Meckling the success corporations had historically enjoyed commanded considerable respect. They acknowledged "there were alternative organizational forms available, and opportunities to invent new ones." ${ }^{87}$ Nevertheless, they noted, "[m]illions of individuals voluntarily entrust[ed] billions of dollars, francs, pesos, etc., of personal wealth" to those running publicly traded companies. ${ }^{88}$ Jensen and Meckling did not lose sight of the fact that there would be managerial agency costs in public firms. Indeed, they asked rhetorically "[h] ow does it happen that millions of individuals are willing to turn over a significant fraction of their wealth to organizations run by managers who have so little interest in their welfare?" 89 Their answer: "the law and the sophistication of contracts relevant to the modern corporation are the products of a historical process in which there were strong incentives for individuals to minimize agency costs." 90

While Jensen and Meckling said there were "strong incentives" for the curtailment of public company agency costs, their analysis of the mechanisms involved was cursory. For instance, even though shareholder voting is a potentially crucial governance mechanism, Jensen and Meckling assumed throughout much of "Theory of the Firm" that all outside equity was non-voting. ${ }^{91}$ Jensen and Meckling did acknowledge that executive pay and takeover activity could be relevant. ${ }^{92}$ Nevertheless, to the extent that Jensen and Meckling sought to explain the

Kelli A. Alces, Balance and Team Production, 38 Seattle U. L. Rev. 187, 194 (2015).

84 See, for example, Lynn A. Stout, The Toxic Side Effects of Shareholder Primacy, 161 U. PA. L. REv. 2003, 2006 (2013).

85 See Cheffins, supra note 56, 39, n. 183, discussing Fama and Jensen, Agency, supra note 19, 328-32; Fama and Jensen, Separation, supra note 19, 312.

86 Jensen and Meckling, supra note 3, 357.

87 Id.

$88 \quad I d$.

$89 \quad I d ., 330$.

$90 \quad I d ., 357$.

$91 \quad I d ., 351$; Bratton and Sepe, supra note 65, 687.

92 Supra notes 70 and 73 and accompanying text. 
apparent containment of agency costs in public companies, they focused primarily on the stock market. They assumed that high agency costs would depress share prices, which would disadvantage proprietors of firms as well as outside investors. ${ }^{93}$ Those in charge correspondingly had a market-driven incentive to reduce agency costs. ${ }^{94}$ Jensen and Meckling were invoking in this context what Jensen referred to elsewhere as "the conservation of value principle," which is "the basic force that motivates both principal and agent, or partners, to minimize the sum of the costs of writing and enforcing (implicit and explicit) contracts through monitoring and bonding." 95

Robert Clark, a distinguished academic corporate lawyer, said of Jensen and Meckling's market-oriented analysis of public companies that " $[\mathrm{t}]$ he strongly suggested conclusion is that existing levels of agency costs are optimal." 96 Jensen and Meckling in fact were hardly unqualified optimists on this front. They acknowledged that steps taken by a company with outside equity to reduce agency costs "cannot reduce these costs to zero" and recognized that the magnitude of agency costs "would vary from firm to firm." that the fact that "agency costs are non-zero" did not mean the agency relationship in firms characterized by a separation of ownership and control was problematically sub-optimal. ${ }^{98}$ To evaluate the public company by way of a zero agency cost benchmark would amount, by their logic, to commission of the "Nirvana fallacy" because other types of business enterprises had their flaws as well. ${ }^{99}$ For Jensen and Meckling, then, the public company was hardly "out of sync" in the market environment in which it was operating. Instead,

The growth in the use of the corporate form as well as the growth in market value of established corporations suggests that at least up to the present, creditors and investors have by and large not been disappointed with the results, despite the agency costs inherent in the corporate form. ${ }^{100}$

Jensen and Meckling's market-oriented optimism regarding the public company's place in the business world is not surprising given their 1970s theoretical priors. As colleagues at the University of Rochester's business school they spent much time considering "the difficulties of encouraging and obtaining effective peaceful cooperation among human beings." ${ }^{101}$ They did so with a deep faith in market outcomes, having studied at the University of Chicago in the 1950s and 1960s when it was "the intellectual home of the idea that markets, not the state, were the proper and most benign central institutions of postwar society." 102 Indeed, for Jensen

\footnotetext{
93 Jensen and Meckling, supra note 3, 327, 345.

94 Id., 328, 349-50. For a summary of the underlying logic, see John Bendickson et al., Agency Theory: Background and Epistemology, 22 J. Mgmt. History 437, 444 (2016).

95 Michael C. Jensen, Self-Interest, Altruism, Incentives, \& Agency Theory, 7(2) J. App. Corp. FIN. 40, 41 (1994).

96 Robert C. Clark, Agency Costs versus Fiduciary Duties in Principals And Agents: The Structure of Business, 55, 65-66 (John W. Pratt \& Richard J. Zeckhauser eds., 1985).

97 Jensen and Meckling, supra note 3, 327, 351.

98 Id., 328.

$99 \quad$ Id

$100 \quad$ Id., 357.

101 Michael C. Jensen, Freedom, Capitalism, and Human Behavior: Chapter 1. Introduction and Overview, 1, working paper (1999), available at http://papers.ssrn.com/abstract=638702.

102 LEMANN, supra note 46, 102, 108-9, 118.
} 
and Meckling it seemed "reasonable to argue that all markets are always in equilibrium, and all forces must always be in balance at all times."103

When Jensen and Meckling's faith in market forces was combined with their characterization of the public company as a nexus of contracting relations, an optimistic verdict regarding the public company logically followed. With a firm being a nexus of contracts, no obvious demarcation exists between the bargains struck in a market environment and intra-firm arrangements. ${ }^{104}$ It correspondingly followed that public companies, as with conventional markets, were presumptively in a state of value-enhancing equilibrium. Or as law professor Michael Klausner has said of conceptualizing relations within firms as contractual, "[i]n the corporate setting, this meant that market forces would lead the parties to create governance arrangements and adopt legal rules that would minimize agency costs and thereby maximize firm value." 105

\section{WHY WHAT JENSEN AND MECKLING SUPPOSEDLY SAID DIFFERS MARKEDLY FROM WHAT THEY ACTUALLY SAID}

The disconnect between what Jensen and Meckling actually said in "Theory of the Firm" and what others have written about the article is by no means unprecedented in the academic realm. Bruno Latour, a specialist in the philosophy of science, wrote in 1987 "a paper may be cited by others ... in a manner far from its own interests" and even "to support a claim which is exactly the opposite of what its author intended." 106 Classic works of scholarship such as "Theory of the Firm" are particularly susceptible to mistranslation because they are often cited and discussed without being carefully read. ${ }^{107}$ Jensen and Meckling's writing style very much lent itself to that treatment. An article that reputedly "prepared the ground for a great remaking of the corporation's relations with government"108 surely should command close attention. However, as a "long, detailed, formula-filled paper" 109 it was destined to test the resolve of even reasonably assiduous readers not fully conversant with rigorous economic analysis.

Michael Jensen's subsequent academic endeavors also contributed substantially to the disconnect between what "Theory of the Firm" supposedly said and actually said. Jensen and Meckling fell out in the mid-1980s after Jensen, seeking to be "close to the world," moved from Rochester to Harvard Business School, which Meckling deemed "intellectually second-rate." 110 Jensen had thus fully embarked on a career "that made him one of the most

103 Michael C. Jensen \& William H. Meckling, The Nature of Man, 7(2) J. ApP. Corp. Fin. 4, 9 (1994). This paper was written at the same time as "Theory of the Firm" but was not published until nearly 20 years later.

104 Brian R. Cheffins, Company Law: Theory, Structure and Operation 36 (1997).

105 Klausner, supra note 35, 1327.

106 Bruno Latour, Science in Action: How to Follow Scientists and Engineers through SocIETy 40 (1987).

107 Mizruchi and Fein, supra note 4, 653.

108 LEMANN, supra note 46, 114.

109 Id., 113.

$110 \quad$ Id., 120. 
influential economists on planet Earth." ${ }^{111}$ Since "the world presented itself to Jensen in bright primary colors," 112 he expressed his views in a forthright manner. Moreover, what Jensen said about corporate America in the 1980s and the early 1990s attracted much attention, reinforced by extensive media coverage. ${ }^{113}$ Subsequent commentators have understandably sought to draw connections between the views Jensen advanced during this period and the famous "Theory of the Firm" work with Meckling. Jensen indeed suggested in the early 2010s that with respect to what he was saying then it was possible to draw "a straight line from where I started back with Bill Meckling working on efficiency in organizations and people."114

While the emphasis on continuity with regard to Jensen's work on the public company is explicable, this has been a misstep. Jensen's views on the public company in fact underwent a 180-degree turn subsequent to the publication of "Theory of the Firm." Mindful of the success the public company had enjoyed as an organizational form, he was an admirer of the public company in the mid-1970s. ${ }^{115}$ By the end of the 1980s, however, he was emphasizing flaws such as "widespread waste and inefficiency" and an "inability to adapt to changing economic circumstances." 116

Jensen's public company pivot has been largely ignored. ${ }^{117}$ As a result, what Jensen said about the public company in the 1980s and early 1990s has become erroneously associated with "Theory of the Firm." This section of the chapter traces the intellectual journey that has obscured what "Theory of the Firm" actually said. We will see initially that Jensen and Meckling knew they were "only beginning to scratch the surface" with respect to firms in 1976. ${ }^{118}$ Next, a deregulation-oriented corporate theory legacy tied to Jensen and Meckling's favorable assessment of the public company will be identified. Finally, we will see why Jensen's public company skepticism began to take hold as he "warmed to his subject."119

\section{A. Scratching the Surface}

Jensen and Meckling's "Theory of the Firm" has been described as a product of America's troubled 1970s economy. Under this view, the article sought to diagnose what ailed America's "out of sync" public companies and prescribe remedies. ${ }^{120}$ In fact, "Theory of the Firm" was not offered as a critique of a flawed corporate America. Instead, Jensen and Meckling thought firms were poorly understood and wrote "Theory of the Firm" to try to improve matters.

Rewinding to the 1970s, it would have been surprising if Jensen and Meckling wrote "Theory of the Firm" to identify corporate ills and propose cures. While public company

\footnotetext{
111 Perlstein, supra note 59. See also Lemann, supra note 46, 101; Michael C. Jensen, 65 J. FIN. vi (2010).

112 LEMANN, supra note 46, 114.

113 Fourcade and Khurana, supra note 36, 369-70.

114 Pioneers in Finance: An Interview with Michael C. Jensen, Jesse Isidor Straus Professor of Business Administration, Emeritus, Harvard Business School (Part II), 2011 J. App. Fin., issue \#1, $6,9$.

115 Supra notes 86-90 and related discussion. 64.

116 Michael C. Jensen, The Eclipse of the Public Corporation, Harv. Bus. Rev., Sept./Oct. 1989, 61,

117 An exception is Doug Henwood, Wall Street: How It Works And for Whom 268-70 (1997).

118 Meckling, supra note 79, 557.

119 Henwood, supra note 117, 268.

120 Supra notes 41-42, 47-53 and related discussion.
} 
executives found themselves in the cross-hairs of considerable social ferment as the decade got underway, contemporaries generally refrained from pointing the finger at corporate America when the country's economy performed poorly in the mid- and late 1970s. ${ }^{121}$ The primary culprits were instead thought to be a sharp spike in oil prices commencing in 1973 and governmental mismanagement of a suddenly ailing economy. ${ }^{122}$ Moreover, Jensen and Meckling began working on "Theory of the Firm" before the 1970s economic slump began. ${ }^{123}$

In 1970, Milton Friedman published a famous essay in the New York Times arguing forcefully that executives should refrain from pursuing ostensibly desirable "social" ends when running their companies. ${ }^{124}$ One way he sought to make this point was to argue that a senior executive of a corporation was in effect an agent of the corporation's shareholders, employees and customers. This agent would, according to Friedman, be "imposing taxes" on these various parties by spending their money in a manner different than they would have spent it, such as by "exercising a distinct 'social responsibility'." 25 Jensen and Meckling were drawn to Friedman's agent analogy and in 1971 began a project that sought to "translate Friedman's journalistic arguments into the language of economics," 126 which ultimately yielded "Theory of the Firm".

Jensen and Meckling's task proved to be more challenging than they had envisaged. Friedman was focusing on what he believed executives should not be doing, ${ }^{127}$ namely running their firms in accordance with their own conception of what was socially beneficial. Jensen and Meckling were engaged in a more open-ended enquiry, seeking to identify incentives managers had to run firms in the profit-maximizing manner economic models presumed. ${ }^{128}$ Consistent with economic orthodoxy Jensen and Meckling assumed "maximizing behavior on the part of all individuals." 129 They struggled to relate this, however, to the notion that firms were profit-maximizing entities. This was because the agenda of self-interested managers could readily depart from a firm-based profit objective. As Jensen said years later of their project, "Bill and I were working on putting this paper together and the more we looked at it, the more we became convinced that we couldn't say that profit maximization was a positive description of what went on in firms. This was the beginning of breaking open the black box of the firm." $" 130$

Note that Jensen referred to the work that he and Meckling were doing that would culminate in "Theory of the Firm" as "the beginning." This implies cognizance of an intellectual journey generally obscured. Nicholas Lemann has characterized Jensen's thinking about economists' traditional assumptions about firms once he and Meckling paid close attention to managerial

\footnotetext{
121 Cheffins, supra note 43, 108-9, 124-25.

122 Id., 109-10.

123 Judith Stein, Pivotal Decade: How the United States Traded Factories for Finance in THE SEventies 101 (2010) ("Before the oil price revolution at the end of 1973, the U.S. seemed to be on the mend").

124 Milton Friedman, The Social Responsibility of Business is to Increase its Profits, N.Y. TIMES, Sept. 13, 1970, Sunday Magazine, 32.

125 Id., 33, 122.

126 Fox, supra note 6, 161. See also Gindis, supra note 8, 6; LEMANN, supra note 46, 112.

127 Fox, supra note 6, 161-62.

128 Id.; LEMANN, supra note 46, 113.

129 Jensen and Meckling, supra note 3, 307.

130 Pioneers in Finance (Part I), supra note 53, 8.
} 
incentives as "Total crap! Makes no sense! Zero! Decades' worth of economic thinking based on a mistake." 131 Jensen no doubt came to believe this over time. "Theory of the Firm" was considerably more cautious, however, with Jensen and Meckling refraining from treating the public company as being badly "out of sync." 132

Jensen and Meckling generated the first draft of what would become "Theory of the Firm" in $1973 .{ }^{133}$ Hostile feedback they received likely contributed to the cautious tone in the published version. Jensen said subsequently that Rochester colleagues "ran us out of the room on a rail." 134 The reaction was similar at the University of Chicago despite the authors and the audience sharing a strong pro-market bias, with people shouting "[h]ow can you say competition does not solve all problems?" 135 Such antagonistic feedback from intellectual allies likely would have made even an academic as strong-willed as Jensen pause.

Also, in the public company context there was an inconvenient fact confronting Jensen and Meckling. Agency costs no doubt were "non-zero" in publicly traded companies run by executives who owned a tiny percentage of shares. ${ }^{136}$ Such firms, however, dominated the American corporate economy. ${ }^{137}$ Given Jensen and Meckling's strong faith in market outcomes, ${ }^{138}$ they could not dismiss this pattern lightly. The result was a somewhat uneasy compromise in "Theory of the Firm." There was praise for the public company, ${ }^{139}$ supported by the observation that "in general" agency costs and monitoring in a firm "will satisfy the conditions of efficiency." 140 But there was a pessimistic public company twist too, with Jensen and Meckling saying that steps taken to address agency costs "will not, however, result in the firm being run in a manner so as to maximize its value." 141 This pessimism, combined with Jensen and Meckling's sidestepping of the topic of corporate purpose, ${ }^{142}$ meant that while "Theory of the Firm" has been closely linked with shareholder primacy ${ }^{143}$ the article neither suggested firms actually maximized shareholder returns nor argued that firms should aim to do so.

\section{B. Deregulation and "Theory of the Firm"}

In an award-winning 1978 article Jensen and Meckling argued that "[t]he corporate form of organization ... is likely to disappear completely." 144 While Jensen and Meckling acknowledged in "Theory of the Firm" that agency costs precluded public companies from maximizing profits in the manner economic theory presumed, this dire prediction was not

131 Lemann, supra note 46, 113.

132 Supra note 100 and accompanying text.

133 Michael C. Jensen et al., Organizations and Markets: History and Development of the Course and the Field, unpublished working paper, 5 (1997), available at https://ssrn.com/abstract=78009.

134 Pioneers in Finance (Part I), supra note 53, 9.

135 Cassidy, supra note 7, 67. See also Pioneers in Finance (Part I), supra note 53, 9.

136 Supra notes 97-98 and accompanying text.

137 Cheffins, supra note 43, 102.

138 Supra notes $102-3$ and related discussion.

139 Supra notes 86-90 and accompanying text.

140 Jensen and Meckling, supra note 3, 327.

141 Id.

142 Supra notes 78-79 and related discussion.

143 Supra notes 56-59 and accompanying text.

144 Cheffins, supra note 43, 106; Michael C. Jensen \& William H. Meckling, Can the Corporation Survive?, FIn. AnAlysts J., Jan./Feb. 1978, 31, 32. 
agency cost-driven. Instead, they argued that the public corporation would fall victim to excessive regulation, with only those firms benefitting from government subsidies being likely to survive ongoing growth in state interference in the market economy. ${ }^{145}$ Jensen and Meckling reaffirmed their regulation-based fears for the future of the public company in the early $1980 \mathrm{~s} .{ }^{146}$ By this point in time, however, whatever threat state intervention posed to the future of the public company was receding. A deregulatory trend that had begun to take hold in the late 1970s was destined to become a cornerstone of Ronald Reagan's presidency after his election in $1980 . .^{147}$

The faith in market forces that Jensen and Meckling shared and which underpinned the positive take on the public company in "Theory of the Firm" found expression in the form of a deregulatory turn that would occur in the corporate law theory realm. In the $1980 \mathrm{~s}$ a "contractarian" approach to corporate law emerged that was strongly influenced by Jensen and Meckling's description of the firm as "a nexus for contracting relationships." 148 This coincided with economists, including Jensen, doing follow-up work on agency costs and the nature of firms that emphasized the role of market forces and corporate contracting as constraints on potential managerial rent-seeking. ${ }^{149}$ According to Bill Bratton, contractarian corporate law scholars working with these economic precepts "translated very skillfully ... an assumption-laden framework ... on an informal basis." ${ }^{150}$ So skillfully in fact that as the 1990s got underway contractarian analysis had moved to the theoretical forefront in American law schools. ${ }^{151}$

As law professors Ed Rock and Michael Wachter have noted, citing Jensen and Meckling, "a central contribution of the nexus approach was to place the corporation into the grand scheme of equilibrating markets." 152 Contractarian corporate lawyers believed, consistent with what Jensen and Meckling argued in "Theory of the Firm", that market forces substantially

145 Jensen and Meckling, supra note 144, 37.

146 Michael C. Jensen \& William H. Meckling, Reflections on the Corporation as a Social Invention, working paper version, 18 (1982), available at http://papers.ssrn.com/abstract=244156; Michael C. Jensen \& William H. Meckling, Corporate Governance and "Economic Democracy": An Attack on Freedom, unpublished working paper, 14 (1983), available at http://papers.ssrn.com/abstract=321521

147 Cheffins, supra note 43, 139-40, 198.

148 Cheffins, supra note 27, 482.

149 William W. Bratton, The Modern Corporation and Private Property Revisited: Gardiner Means and the Administered Price, 42 Seattle U. L. Rev. 591, 595, 614-15 (2019) (describing a 1982 conference where free-market oriented economists such as Jensen and Eugene Fama gave a series of papers that emphasized market forces to cast doubt on insights provided by Adolf Berle and Gardiner Means' work on the separation of ownership and control. Frank Easterbrook and Daniel Fischel, the pre-eminent contractarian corporate law scholars, attended. Two articles by Jensen and Fama would be published as part of the conference proceedings - Fama \& Jensen, Agency, supra note 19; Fama \& Jensen, Separation, supra note 19).

150 Bratton, supra note 2, 763.

151 Supra notes 27-28 and accompanying text.

152 Edward B. Rock \& Michael L. Wachter, Islands of Conscious Power: Law, Norms, and the Self-Governing Corporation, 149 U. PA. L. REv. 1619, 1628 (2001). 
counteracted potential abuse from managerial discretion. ${ }^{153}$ A contractarian aversion to regulatory intervention via corporate law resulted. ${ }^{154}$ As Rock and Wachter have said:

As a continuing theory, the nexus of contracts serves as a powerful metaphor, focusing on the voluntary nature of the firm. As a positive statement, it describes statutes that regulate organizations as primarily enabling rather than mandatory, with individual terms serving as defaults which, while designed to meet the needs of most drafters, can be overwritten when they do not. ${ }^{155}$

Ironically, as we will see next, at the same time the trust in the market underpinning the analysis of public companies in Jensen and Meckling's "Theory of the Firm" was achieving prominence in corporate law scholarship via contractarian analysis, Jensen's faith in the public company would largely dissipate.

\section{Jensen Loses Faith in the Public Company}

For Michael Jensen his writing with William Meckling from the mid-1970s through to the early 1980s was merely an initial step in work on the public company that would ultimately involve a marked shift in attitude. It is hardly a revelation that Jensen could change his mind. For instance, "a long strange intellectual voyage" 156 involving the efficacy of share prices has been widely reported. ${ }^{157}$ Jensen wrote in 1984 that "a security's market price represents the best available estimate of its true value." ${ }^{158}$ By 2002 he was condemning a "dysfunctional conversation between Wall Street" and public company executives focusing on corporate earnings which Jensen said resulted in mispricing, and more precisely "overvalued stock." 159 Not nearly as widely appreciated is how Jensen went from being a 1970s fan of the public company to an academic arguing by the 1990s "stockholders can't trust the managers they've hired to run their corporations, and a radical realignment is in order." 160 Jensen's intellectual voyage, strongly influenced by takeover trends, was largely complete as the 1990s began. His change of heart is crucial for present purposes because it does much to explain the mischaracterizations of "Theory of the Firm" canvassed in Part II.

In 1983 Jensen and Meckling acknowledged it was "embarrassing to admit that, after several hundred years, social scientists have not yet developed a thorough understanding of the advantages and disadvantages of publicly held profit seeking corporations versus other

153 Wolfson, supra note 75, 966; Frank H. Easterbrook \& Daniel R. Fischel, The Corporate Contract, 89 Colum. L. Rev. 1416, 1419 (1989) (both citing Jensen and Meckling).

154 Henry N. Butler, The Contractual Theory of the Corporation, 11 Geo. Mason U. L. Rev. 99, 121-23 (1989). See also Matthew T. Bodie, The Post-Revolutionary Period in Corporate Law: Returning to the Theory of the Firm, 35 Seattle U. L. Rev. 1033, 1047 (2012) (summarizing the reasoning).

155 Rock and Wachter, supra note 152, 1628.

156 Fox, supra note 6, 267.

157 Id., 191-92, 205, 267-69, 283-86; LemanN, supra note 46, 120-22, 127-29; Jeff Madrick, Economic Scene, N.Y. Times, Feb. 20, 2003, C2. See also Perlstein, supra note 59 (saying that with Jensen's views regarding the rationality of individuals there was "a transition ... almost too absurd to believe").

158 Jensen, Takeovers, supra note 72, 113.

159 Joseph Fuller \& Michael C. Jensen, Just Say No to Wall Street: Putting a Stop to the Earnings Game, 14(4) J. App. Corp. Fin. 41, 42 (2002).

160 Henwood, supra note 117, 265. 
forms of organizations." ${ }^{161}$ Nevertheless, they remained fans of the public company, saying that "the corporation as a social invention has been enormously productive and therefore able to survive in the wide open competition among organizational forms." 162 Jensen, for his part, was prepared to go further than he and Meckling had been in 1976 to explain the public company's success. In a 1984 article where he sought to debunk pessimistic takeover "folklore" he said that it was "difficult to observe" the "subtle" ways in which corporate executives were induced to act in the shareholders' interests. ${ }^{163}$ Jensen did acknowledge, though, that boards of directors would replace underperforming managers when "internal control mechanisms are working well." "164 Moreover, "[w] hen these mechanisms break down" shareholders "receive protection from the takeover market, where alternative management teams compete for the rights to manage the corporation's assets." 165

Takeovers would loom large in Jensen's 1980s thinking about the efficacy of the public company. He was offering his views on takeover folklore in the same year as the Washington Post said "[a] barrage of takeovers is blasting its way through the corridors of corporate America." 166 The 1980s would ultimately become "the Deal Decade," where takeover-related activities preoccupied executives, commentators and the public to an unprecedented extent. ${ }^{167}$ When the tide ultimately turned against takeovers Jensen's faith in the public company drained away.

Jensen acknowledged in a 1988 article analyzing empirical evidence on takeovers that "corporate control transactions and the restructurings that often accompany them are frequently wrenching events in the lives of those linked to the involved organizations: the managers, employees, suppliers, customers and residents of surrounding communities." 168 Nevertheless, Jensen was a takeover enthusiast. This was partly due to the disciplinary properties of the market for corporate control in the public company context. In his 1988 article on takeovers he said that when agency costs "are large, the threat or actuality of takeovers can reduce them."169 Jensen also believed that takeovers were beneficial for the broader American economy. In a 1987 op-ed in the Wall Street Journal he maintained that "the restructuring of corporate America ... that is being brought about by the takeover market is streamlining many of the largest and most complex corporations that are simply too large, too complicated and too unfocused to be efficient." 170

In his 1987 Wall Street Journal op-ed on takeovers Jensen made a plea- "We must not strangle these productive forces." ${ }^{171}$ He was aware that takeovers had strong opponents, led by "top-level managers of many of the largest and most inefficient corporations ... threatened

\footnotetext{
161 Jensen and Meckling, Corporate Governance, supra note 146, 14.

162 Id., 14-15.

163 Jensen, Takeovers, supra note 72, 119.

164 Id.

165 Id.

166 David A. Vise, Pace of High-Priced Corporate Mergers Seen Continuing, WAsh. Post, Sept. 16, 1984, H22.

167 Cheffins, supra note 43, 155.

168 Michael C. Jensen, Takeovers: Their Causes and Consequences, 2 J. Econ. Persp. 21, 21-22

169 Id., 28.

170 Michael C. Jensen, A Helping Hand for Entrenched Managers, Wall St. J., Nov. 4, 1987, 36.

171 Id.
} (1988). 
with the loss of their jobs by takeovers." ${ }^{172}$ A front-line tactic public company executives could use to thwart an unwelcome takeover bid was to invoke takeover defenses. As the 1980s got underway Jensen and Meckling, consistent with their long-standing faith in market outcomes, were prepared to give managers the benefit of the doubt with regard to resisting unwelcome bids, saying "anti-takeover provisions often enhance the price target shareholders ultimately are paid in a subsequent takeover." ${ }^{173}$ By 1988, Jensen was a robust takeover defense skeptic, arguing "[a]ctions by managers that eliminate or prevent offers or mergers are most suspect as harmful to shareholders." 174

Legal trends helped to induce Jensen's change of heart, with Delaware court rulings in 1985 getting the process underway. In Moran v. Household International Inc., the first case where Delaware courts were called upon to assess the validity of the anti-takeover device known as a poison pill, ${ }^{175}$ Jensen testified that the pill Household International Inc. had adopted was likely to have an adverse impact on shareholders. ${ }^{176}$ When the Delaware judiciary upheld use of this takeover defense mechanism, Jensen said this was "incredible" and "fundamentally change[d] shareholders' rights." 177 Likewise, when the Delaware Supreme Court ruled in Unocal Corporation v. Mesa Petroleum Co ${ }^{178}$ that the board of a takeover target could make a discriminatory self-tender offer so as to thwart a raider's plans, Jensen described the ruling as "ludicrous," "an incredible victory" for the target's chairman of the board and "a loss for all the rest of us." 179

Jensen's reaction was similar when states began enacting anti-takeover legislation in the late 1980s, with the U.S. Supreme Court giving the green light in 1987 in CTS Corp. v. Dynamics Corp. of America. ${ }^{180} \mathrm{He}$ attributed a wave of anti-takeover statute enactments that would ensue to lobbying by "top level corporate managers and other groups who stand to lose from competition in the market for corporate control." 181 He said the trend was "another example of special interests using the democratic political system to change the rules of the game to benefit themselves at the expense of society as a whole." 182

Jensen drew general negative inferences about managerial priorities from the executive backlash against takeovers. While he and Meckling emphasized in "Theory of the Firm" in 1976 that public company executives were successfully delivering value for investors despite agency costs, ${ }^{183}$ a decade later Jensen was saying the public company was "fraught with

172 Id.

173 Jensen and Meckling, Reflections, supra note 146, 16.

174 Jensen, supra note 168, 23.

175 Dosoung Choi, Sreenivas Kamma \& Joseph Weintrop, The Delaware Courts, Poison Pills, and Shareholder Wealth, 5 J. L. ECON. \& ORG. 375, 378 (1989).

176 Moran v. Household International Inc. 490 A.2d 1059, 1067-68 (1985).

177 David Clark Scott, Some Big-Block Investors Fight Company Efforts to Foil Takeovers, CHRIS. ScI. Monitor, May 3, 1985, 21. Jensen was commenting on the trial court decision, which was upheld on appeal-500 A.2d 1346.

178 Unocal Corp. v. Mesa Petroleum Co., 493 A.2d 946 (Del. 1985).

179 Nancy Rivera \& Debra Whitefeld, Unocal Win May Dampen Takeovers, L.A. Times, May 22, $1985, \mathrm{~F} 1$.

180481 U.S. 69 (1987).

181 Jensen, supra note 168, 45-46. Nearly 40 states ultimately enacted such laws-CHEFFINS, supra note $43,177$.

182 Jensen, supra note $168,45$.

183 Supra note 100 and related discussion. 
conflicting interests." ${ }^{184}$ He reiterated the point in 1988, arguing "[e]vidence on management actions taken to forestall takeovers is inconsistent with the view that management always acts in shareholders' interest." 185

Jensen's emerging public company pessimism coincided with him elaborating on the nature of agency costs. He accused large public companies of accumulating counterproductively large amounts of "free cash flow" (money left over after all likely to be profitable projects had been funded) that executives were prone to squander by engaging in vanity-driven empire-building or by building up a financial cushion to protect themselves in the event of tough times. ${ }^{186}$ Jensen argued in the New York Times in 1986 that "[c]ompanies with high agency costs due to high free cash flows and poor future investment prospects are highly likely to be takeover candidates." 187 Jensen correspondingly feared that to the extent managerial lobbying forestalled takeover activity there would be "a reduction in efficiency and a significant weakening of the corporation as an organizational form." 188

Jensen did retain substantial residual faith in corporate enterprise as the 1980s began to draw to a close. In a 1988 interview with Business Week he said "the corporation is a fabulous invention - the most important thing since the invention of the wheel." 189 By this point in time, however, Jensen was poised to lobby for a major recalibration of the financial incentives of corporate executives. His position on this issue evolved quickly, ultimately betraying a substantial loss of confidence in public company executives and the efficacy of the public company more generally.

In a 1984 piece in the New York Times co-authored with Kevin Murphy, Jensen chastised critics of executive pay, arguing that the available empirical evidence showed "executive salaries are determined by the market, and that changes in compensation are strongly related to company performance." 190 This optimistic stance was consistent with the faith in market outcomes that underpinned the analysis Jensen and Meckling offered in "Theory of the Firm." By 1988, however, Jensen was warier of the merits of then prevailing managerial compensation arrangements, saying that "[o]ur economic understanding of internal incentive structures is far from complete." 191 A paper he was working on with Murphy that indicated "actual executive-compensation contracts look very different from those predicted by economic theory" no doubt influenced his views. ${ }^{192}$ In 1990 Jensen and Murphy went further, publishing a widely heralded "call to arms" 193 in the Harvard Business Review in which they urged public

184 Jensen, supra note 19, 323.

185 Michael C. Jensen \& Jerold B. Warner, The Distribution of Power Among Corporate Managers, Shareholders, and Directors, 20 J. FIN. ECON. 3, 4 (1988).

186 Jensen, supra note 19, 323; Jensen, supra note 168, 28.

187 Jensen, How, supra note 72.

188 Jensen, supra note 168, 46.

189 Meet Mike Jensen, the Professor of Merger Mania, Bus. Wк., Feb. 8, 1988, 66, 67.

190 Michael C. Jensen \& Kevin J. Murphy, Beware the Self-Serving Critics of Executive Pay, N.Y. Times, May 20, 1984, F2. See also Michael C. Jensen \& Jerold L. Zimmerman, Management Compensation and the Managerial Labor Market, 7 J. Accting. \& Econ. 3, 4 (1985).

191 George P. Baker, Michael C. Jensen \& Kevin J. Murphy, Compensation and Incentives: Practice vs. Theory, 43 J. FIn. 593, 593 (1988).

192 Id., 610, citing Michael C. Jensen \& Kevin J. Murphy, Are Executive Compensation Contracts Structured Properly?, Harvard Business School and University of Rochester Working Paper, February 1988.

193 Roger Lowenstein, Origins of the Crash: The Great Bubble and its Undoing 15 (2004). 
company boards to incentivize managerial compensation, arguing in so doing that most senior executives behaved like bureaucrats because pay levels barely varied in accordance with corporate performance. ${ }^{194}$ They singled out for praise the Berkshire Hathway conglomerate, saying that the 45 per cent ownership stake its CEO Warren Buffett held was "a powerful incentive to avoid wasteful spending." 195

There was a similar timeline with even more radical public company medicine that Jensen ultimately prescribed, the public-to-private buyout. For Jensen in 1984 such transactions still seemed quite exotic in nature. When debunking takeover folklore he provided a brief synopsis of "going private" deals where an incumbent management team bought up all of a public company's shares and in so doing acknowledged that "[o]n occasion, when going private is a leveraged buy out, management shares the equity with private investors." 196 In fact, by that point in time outside investors had begun to sign up enthusiastically to participate in leveraged buyouts via investment funds akin to KKR's pioneering 1978 private equity fund. ${ }^{197}$

In 1985 the New York Times referred to leveraged buyouts as "the business world's latest craze." 198 Jensen was quoted as saying of the phenomenon "[w]e are developing new organizational forms to compete with the publicly held company, and it is an interesting experiment to watch." 199 Despite this tentative verdict his emerging skepticism of the public company was becoming evident as he added "[f]or many areas of the economy, the broadly held corporation is a dodo." ${ }^{200}$ He was somewhat more cautious in his 1988 article analyzing empirical evidence relating to takeovers, saying leveraged buyouts were "creating a new organizational form that competes successfully with the open corporate form." ${ }^{201}$ Jensen largely threw caution to the wind, however, when in the following year he published an article in the Harvard Business Review provocatively titled "The Eclipse of the Public Corporation."202

Jensen, to make his case in "Eclipse" that the public company had "outlived its usefulness in many sectors of the economy," cited chronic inefficiency and a lack of adaptability. ${ }^{203} \mathrm{He}$ also drew attention to the governance advantages that leveraged buyouts ostensibly offered. These included highly incentivized managerial compensation in companies taken private by LBOs and the beneficial discipline the substantial debt used to finance leveraged public-to-private deals imposed on managerial discretion. ${ }^{204}$ Jensen also emphasized that firms such as KKR that organized buyout transactions - he labelled them "LBO associations"-would monitor management more effectively than the "remarkably powerless" institutional shareholders that owned the bulk of the shares in publicly traded companies. ${ }^{205}$ This was because LBO association proprietors took "the bulk of their compensation as a share in the [acquired] companies'

\footnotetext{
194 Jensen and Murphy, supra note 71.

195 Id., 141.

196 Jensen, Takeovers, supra note 72, 118.

197 Supra note 76 and accompanying text; Cheffins and Armour, supra note 76, 19.

198 Leslie Wayne, Buyouts Altering Face of Corporate America, NY TIMEs, Nov. 23, 1985, 1.

199 Id.

200 Id. See also Elaine Johnson \& Alan Deutschman, Business Schools Revise Courses to Include Restructuring Issues, WaLl ST. J., Aug. 12, 1985, 13 (Jensen saying giving managers big equity stakes in companies taken private was "putting the wolf at the door").

201 Jensen, supra note 168, 31.

202 Jensen, supra note 116.

203 Id., 61; supra note 116 and related discussion.

204 Jensen, supra note 116, 68-70.

205 Id., 66.
} 


\section{Research handbook on corporate purpose and personhood}

increased value." ${ }^{206}$ Ultimately, business enterprises taken private by LBO funds were well positioned to displace the public company because "the new organizations ... eliminate much of the loss created by conflicts between owners and managers, without eliminating the vital functions of risk diversification and liquidity once performed exclusively by public equity markets." ${ }^{207}$

Just as a deregulatory movement undercut Jensen's late 1970s speculation that government interference jeopardized the public company, ${ }^{208}$ economic trends sideswiped his 1989 eclipse prediction. The Deal Decade came to a shuddering halt as the 1980s ended. This stopped both public-to-private buyouts and hostile takeovers dead in their tracks. ${ }^{209}$ The 1990s, moreover, proved to be a banner decade for the public company. Share prices surged and for the first time ever the aggregate market capitalization of publicly traded stocks exceeded U.S. gross domestic product. ${ }^{210}$

Even though it soon became clear that Jensen's declaration of a public company eclipse "was, at best, premature" 211 he was not prepared to cut the public company any slack. Having taken on board the end of the 1980s" "shutdown of the capital markets as an effective mechanism for motivating change, renewal, and exit," Jensen's antipathy toward the public company moved fully to the forefront, most prominently in his 1993 presidential address to the American Financial Association. ${ }^{212}$ Jensen's nostalgia for the market-oriented discipline of takeovers and leveraged buyouts was palpable. In 1991 he said that "[t]he effect of such transactions was to transfer control over vast corporate resources - often trapped in mature industries or uneconomic conglomerates - to those prepared to pay large premiums to use those resources more efficiently," which fostered "a pronounced trend toward smaller, more focused, more efficient — and in many cases private - corporations." ${ }^{13}$ Jensen was well aware that the threat of a takeover was by no means the only market-driven constraint corporations faced, describing the discipline arising from competition from rivals as "inevitable." 214 However, in stark contrast with the Chicago economists who took Jensen and Meckling to task for underestimating the power of competition as they were developing their theory of the firm, ${ }^{215}$ Jensen maintained in his 1993 presidential address that "the product and factor markets [were] slow to act as a control force" and often kicked into operation "too late" to preclude a substantial "waste of resources." 216

\footnotetext{
206 Id., 70.

207 Id., 64.

208 Supra note 147 and accompanying text.

209 Cheffins, supra note 43, 172.

210 Id., 227-28.

211 Margaret M. Blair, Who's in Charge Here? How Changes in Corporate Finance are Changing Corporate Governance, BrookInGs ReV., Fall, 1991, 9, 13.

212 Michael C. Jensen, The Modern Industrial Revolution, Exit, and the Failure of Internal Control Systems, 48 J. FIn. 831, 852 (1993). See also Michael C. Jensen, Corporate Control and Politics of Finance, J. App. Corp. Fin., Summer 1991, 13; Michael C. Jensen (with Donald H. Chew), U.S. Corporate Governance Lessons from the 1980s in The PoRTABLE MBA IN Investment 377 (Peter Bernstein, ed., 1995).

213 Jensen, Corporate, supra note 212, 13. See also Jensen, U.S., supra note 212, 378.

214 Jensen, Modern, supra note 212, 850.

215 Supra note 135 and accompanying text.

216 Jensen, Modern, supra note 212, 850.
} 
Jensen reasoned that with the market for corporate control having become moribund and with competition from rivals only imposing discipline belatedly, "we are left to depend on the internal control system to act to preserve organizational assets." ${ }^{217}$ Here, Jensen felt, public companies were falling badly short. He said "ineffective governance is a major part of the problem with internal control mechanisms," ${ }^{18}$ which meant these mechanisms "react too late, and they take too long to effect major change." 219 Jensen said that as a result "[m]any of our best known companies - GM, IBM, and Kodak come to mind most readily - have wasted vast amounts of resources over the last decade or so." ${ }^{220}$ His verdict, based on this evidence, was that the internal control mechanisms in America's public companies had "failed." 221 A 1997 Journal of Finance survey of corporate governance pithily summed up Jensen's verdict on America's corporate governance system - "deeply flawed." 222 This indeed was an emphatic 180-degree turn for an academic who had characterized the American public company as an "awesome social invention" less than twenty years earlier. ${ }^{223}$

\section{CONCLUSION}

Governance arrangements in American public companies changed markedly as the 20th century drew to a close. ${ }^{224}$ Independent directors moved center stage as the monitoring role of boards was prioritized. The market for corporate control operated at an unprecedented pace in the 1980s before receding dramatically in the 1990s. Incentivizing executive pay became a top priority in public company boardrooms. Maximizing shareholder value rose to the top of the managerial priority list. During the same period these trends were in operation Michael Jensen and William Meckling's 1976 "Theory of the Firm" article was becoming one of the most widely cited papers ever in the governance field, as well as in various related disciplines. ${ }^{225}$ Numerous observers have inferred in turn that Jensen and Meckling helped to inspire the governance changes America's public companies underwent as the 20th century drew to a close. As Part II of this chapter indicates, the dots in fact do not connect up in this way.

While Jensen and Meckling's "Theory of the Firm" has been cited astonishingly often, it did not act as the catalyst for late-20th-century corporate governance trends in the manner it seemingly could have. The reason is straightforward. Jensen and Meckling's pioneering work on agency costs and the nature of the firm would provide a theoretical framework that would subsequently be drawn upon to press the case for governance changes, which more than suf-

\footnotetext{
$217 \quad I d ., 852$.

218 Id.

219 Jensen, U.S., supra note 212, 396.

${ }^{220} I d$., 380. On the travails of these and various other leading U.S. companies in the early 1990 s, see CHEFFINS, supra note 43, 234-35, 259.

221 Jensen, Modern, supra note 212, 852-53.

${ }^{222}$ Andrei Shleifer \& Robert W. Vishny, A Survey of Corporate Governance, 52 J. FIN. 737, 737 (1997).

223 Supra note 86 and related discussion.

224 For an overview, see Brian R. Cheffins, The History of Corporate Governance in THE OXFORD Handbook of Corporate Governance 46 (Mike Wright, Donald Siegel, Kevin Keasey \& Igor Filatotchev, eds., 2013).

${ }^{225}$ Supra note 8 and related discussion; Boris Durisin \& Fulvio Puzone, Maturation of Corporate Governance Research, 1993-2007: An Assessment, 17 CoRp. Gov. 266, 271-72 (2009).
} 
fices to position "Theory of the Firm" in the academic pantheon. The article itself, however, only dealt in a cursory way with boards, takeovers, managerial compensation and corporate purpose, and did not advance a case for reform on any of these fronts. This is hardly surprising, given Jensen and Meckling's views on the public company. They inferred from the success it had historically enjoyed as an organizational form that there must be "strong incentives for individuals to minimize agency costs." ${ }^{226}$ Why press a case for change?

Jensen's subsequent scholarship helps to explain why "Theory of the Firm" has been credited erroneously for directly fostering influential late-20th-century governance trends. His views on the public company took a 180-degree turn from 1976 through to the early 1990s, and he became a forceful advocate for change. There has been an unsurprising tendency amongst commentators to emphasize continuity with Jensen's public company theorizing when in fact there was little. Still, while the disconnect between what "Theory of the Firm" supposedly and actually said is explicable, there is no reason for this to continue. Those seeking to explain and critique public company governance trends arising from the mid-1970s onward should treat Jensen and Meckling's 1976 analysis as a supporting player rather than as a star of the show.

226 Supra note 90 and accompanying text. 